\title{
Meningkatkan hasil belajar murid melalui model (TGT) teams Games \\ Tournament dalam pembelajaran PKn kelas IV SD Negeri 26 Tamanroja \\ Kecamatan Labakkang Kabupaten Pangkep
}

\author{
Rismawati ${ }^{1)}$ \& Mardiana ${ }^{2)}$ \\ Pendidikan Pancasila dan Kewarganegaraan FKIP Universitas Muhammadiyah Makassar ${ }^{1)}$ \\ Pendidikan Pancasila dan Kewarganegaraan FKIP Universitas Muhammadiyah Makassar 2) \\ rismawati@unismuh.ac.id ${ }^{1)}$ \& mardiana@unismuh.ac.id ${ }^{2)}$
}

\begin{abstract}
This study can improve the learning outcomes of Civics through the learning model TGT (Team Tournament Match) in the fourth class in SD 26 Tamanroja Sub-district Labakkang Pangkep regency. This type of research is a classroom action research (classroom action class) consisting of 2 cycles where each cycle is held 4 times a meeting. Implementation procedures, observation and reflection. Subjects in this study were fourth grade students of SD Negeri 26 as many as 44 people. The collected data were analyzed using quantitative and qualitative analysis. The result of quantitative analysis shows that there is an increase of learning result which can be seen from average score in cycle I due to student learning result equal to 69,13 with ideal score 100 which is in low category, whereas in cycle II become 79,09 with ideal score 100 that is in the medium category. Qualitatively expected to increase in language, active, and student motivation to learn Civics. Based on the results of this study can be concluded in the learning PKN through learning model teams tournament games (TGT) can improve the learning outcomes of fourth grade students of SD Negeri 26 Tamanroja District Labakkang Pangkep District.
\end{abstract}

Keywords: Learning Outcomes, Tournament Match Team (TGT), Student

\begin{abstract}
Abstrak. Penelitian ini bertujuan meningkatkan hasil belajar PKn melalui model pembelajaran TGT (Teams Games Tournament) pada kelas IV di SD 26 Tamanroja Kecamatan Labakkang Kabupaten pangkep. Jenis penelitian ini adalah penelitian tindakan kelas (class action classroom) yang terdiri dari 2 siklus dimana setiap siklus dilaksanakan 4 kali pertemuan. Prosedur penelitian meliputi perencanaan, pelaksanaan tindakan, observasi dan refleksi. Subjek dalam penelitian ini adalah murid kelas IV SD Negeri 26 sebanyak 44 orang. Data yang terkumpul dianalisis dengan menggunakan analisis kuantitatif dan kualitatif. Hasil analisis kuantitatif menunjukkan bahwa terjadi peningkatan hasil belajar yang terlihat dari skor rata-rata pada siklus I diperoleh hasil belajar murid sebesar 69,13 dengan skor ideal 100 yang berada pada kategori rendah, sedangkan pada siklus II menjadi 79,09 dengan skor ideal 100 yang berada pada kategori sedang. Secara kualitatif terjadi peningkatan dalam perubahan sikap murid, keaktifan, serta motivasi siswa belajar PKn. Berdasarkan hasil penelitian ini dapat disimpulkan bahwa dalam pembelajaran PKn melalui model pembelajaran teams games tournament (TGT) dapat meningkatkan hasil belajar PKn murid kelas IV SD Negeri 26 Tamanroja Kecamatan Labakkang Kabupaten Pangkep. Kata Kunci: Hasil Belajar, Teams Games Tournament (TGT), Siswa
\end{abstract}




\section{PENDAHULUAN}

Kedisiplinan belajar dapat ditanamkan kepada siswa-siswi melalui beberapa pembelajaran di kelas. Pilihan pembelajaran atau model pembelajaran merupakan bagian yang penting dan membutuhkan kejelian serta inovasi guru dalam proses transformasi ilmu pengetahuan atau nilainilai. Pada dasarnya manusia membutuhkan pendidikan dalam kehidupannya, baik pendidikan formal maupun pendidikan non-formal, agar dengan pendidikan potensi dirinya dapat berkembang melalui proses pembelajaran atau cara lain yang dikenal dan dilakukan oleh masyarakat. Lahirnya generasi baru yang cerdas dan handal adalah suatu keharusan bagi suatu bangsa, para pendidik (guru) serta orang tua. Seperti yang tercermin dalam nilai-nilai mata pelajaran PKn, bahwa masa depan bangsa ditentukan oleh generasi muda yang cerdas.

Pendidikan merupakan bidang pembangunan yang sangat menentukan kelangsungan hidup individu,masyarakat bangsa dan Negara di Indonesia Tujuan pendidikan secara umum tertuang dalam undang-Undang Sistem Pendidikan Nasional tahun 2003 adalah :Mencerdaskan kehidupan Bangsa, bertujuan untuk berkembangnya potensi peserta didik agar menjadi manusia yang beriman dan bertakwa kepada Tuhan Yang Maha Esa, berakhlak mulia, sehat, berilmu, cakap, kreatif, mandiri, dan menjadi warga Negara yang demokratis serta bertanggung jawab (UU RI No .20 Tahun 2003,2007:3)

Upaya meningkatkan aktivitas belajar murid merupakan tantangan yang selalu dihadapi oleh setiap orang yang berkecimpung dalam profesi keguruan dan pendidikan. Banyak upaya yang telah dilakukan dan banyak pula keberhasilan yang telah dicapai, meskipun keberhasilan itu belum sepenuhnya memberikan kepuasan bagi masyarakat dan para pendidik, sehingga sangat menuntut renungan, pemikiran dan kerja keras orang-orang yang berkecimpung di dunia pendidkan untuk memecahkan masalah yang dihadapi.

Proses dan pemecahan masalah pembelajaran di kelas dapat dilakukan melalui berbagai cara, misalnya melalui diskusi kelas, tanya jawab antara guru dan peserta didik, inquiry dan metode-pembelajaran lain. Oleh karena itu seorang guru dituntut untuk dapat membawa dirinya sebagai agen pembawa informasi dengan baik. Guru yang kreatif selalu mencari pendekatan baru dalam memecahkan masalah, tidak terpaku pada cara tertentu yang monoton. Untuk melaksanakan proses pebelajaran perlu dipikirkan pembelajaran yang tepat. Pemilihan pembelajaran disamping harus disesuaikan dengan materi dan tujuan pembelajaran juga ditetapkan dengan melihat kegiatan yang akan dilakukan, pembelajaran sangat beraneka ragam, guru dapat memilih pembelajaran pembelajaran yang efektif untuk mengantarkan murid mencapai tujuan.

Keberhasilannya proses belajar mengajar sangat ditentukan oleh seorang guru yang melakukan transfer ilmu (knowledge transfer) melalui proses pembelajarannya, dalam hal ini strategi pembelajaran menjadi penting dalam proses belajar tersebut. Banyak pembelajaran pembelajaran di kelas yang dilakukan oleh para guru, pembelajaran yang sering digunakan dalam proses pembelajaran tersebut, antara lain: pembelajaran ceramah, pembelajaran tanya jawab, pembelajaran diskusi, pembelajaran pemberian tugas, pembelajaran demontrasi, pembelajaran karyawisata, kerja kelompok (inquiri), pembelajaran bermain peran, pembelajaran dialog, pembelajaran bantah membantah, dan pembelajaran bercerita (Sudrajat, 2009).

Kemampuan guru dalam memilih dan memilah metode, yang relevan dengan tujuan dan materi pelajaran merupakan kunci keberhasilan dalam pencapaian prestasi belajar siswa. Tuntutan tersebut mutlak dilakukan oleh seorang guru, apabila melalukan transfer ilmu khususnya PKn. Hal tersebut juga sejalan dengan tuntutan kurikulum saat ini yang sangat memperhatikan kepentingan pembelajaran yang akan digunakan. Terdapat banyak strategi pembelajaran, dan dari sekian banyak pembelajaran tersebut, dapat dikatakan bahwa tidak ada model pembelajaran yang lebih baik dari pada model pembelajaran satu dengan model pembelajaran yang lain. 
Berdasarkan pengamatan peneliti pada observasi awal pada tanggal 17 maret proses belajar mengajar mata pelajaran PKn murid kelas IV SD Negeri 26 Tamanroja diketahui bahwa masih terdapat beberapa masalah yang kiranya perlu dipecahkan oleh guru sehingga tujuan pembelajaran PKn dapat tercapai secara maksimal. Masalah-masalah tersebut antara lain: 1) dari sisi guru; berupa penguasaan kelas yang kurang, pengelolaan proses belajar mengajar yang terkesan biasa saja, kurang sistematis, intensitas tugas kelas yang kurang, guru kurang menstimulus aktivitas belajar murid, membiarkan murid yang bermain dengan sesama rekannya, tidak memberikan teguran kepada murid yang ribut, sedangkan 2) dari sisi murid antara lain; banyak murid kurang aktif dalam proses belajar mengajar dengan ciri-ciri; kurang bahkan tidak mengajukan pertanyaan dari materi yang diajarkan, tidak memberikan jawaban atas pertanyaan guru, kurangnya perhatian murid terhadap materi yang dijelaskan guru, bermain dengan sesama rekannya, murid berkeliaran di luar kelas, hal lainnya yaitu; murid kurang antusias mengikuti pelajaran yang ditunjukkan dengan ciriciri; murid tidur dengan menundukkan kepala, bercerita dan bermain secara sembunyi-sembunyi kepada sesama rekannya di bangku tengah dan belakang. Dampaknya adalah hasil belajar pada ulangan formatif secara klasikal mendapat nilai rata-rata kelas 60,80 dengan murid yang tuntas hanya mencapai 23 orang 45,09 dari 44 jumlah murid dengan kriteria ketuntasan minimal ( $K K M$ ) belajar murid 63 .

Berdasarkan latar belakang yang diidentifikasi pada proses belajar mengajar mata pelajaran PKn pada murid kelas IV SD Negeri 26 Tamanroja di atas, maka salah satu pemecahan masalah yang dapat dilakukan oleh peneliti adalah dengan model Teams Games Tournament ( TGT). Teams Games Tournament (TGT) berdasarkan hasil penelitian yang akan dilakukan oleh peneliti pada murid kelas IV SD negeri 26 Tamanroja dapat meningkatkan aktivitas, antusiasme, dan prestasi belajar murid.

Di samping keberhasilan penerapan pembelajaran Teams Games Tornament (TGT) dalam meningkatkan hasil belajar, antusiasme dan prestasi belajar murid kelas IV SD Negeri 26 Tamanroja di atas, beberapa alasan penggunaan pembelajaran Teams Games Tournament (TGT) pada mata pelajaran PKn murid kelas IV SD Negeri 26 Tamanroja antara lain: (1) Memberikan pengalaman langsung kepada murid untuk memecahkan masalah yang dihadapinya secara nyata, (2) dengan pembelajaran bermain peran membantu murid menentukan makna-makna kehidupan dari lingkungan sosial yang bermanfaat bagi dirinya, dan (3) melatih murid untuk menjunjung tinggi nilai-nilai demokratif sekaligus bertanggung jawab dalam mengimplementasikan nilai-nilai pancasila (Mudaimin, 2008)

Berdasarkan alasan di atas, maka peneliti merasa tertarik sekaligus melatar belakangi penulis untuk mengkaji lebih dalam tentang pembelajaran Teams Games Tournament (TGT) terkait dengan upaya meningkatkan hasil belajar mata pelajaran PKn murid kelas IV SD Negeri 26 Tamanroja.

\section{METODE PENELITIAN}

Penelitian ini merupakan jenis penelitian tindakan kelas (classroom action research). Penelitian tindakan kelas ini direncanakan dalam 3 siklus, yang tiap-tiap siklusnya mencakup tahapan perencanaan (planning), tindakan (acting), pengamatan/observasi (observing), refleksi (reflecting). Penelitian ini di laksanakan di kelas IV SD Negeri 26 Tamanroja dengan jumlah siswa 44 orang yang terdiri dari laki-laki 17 dan perempuan 27 orang.

Penelitian di desain dengan dalam dua siklus kegiatan, dimana pada masing-masing siklus terdiri dari (4x) empat kali kegiatan tatap muka, sehingga total kegiatan tatap muka selama dua siklus adalah (8x) empat kali pertemuan. Instrumen dari penilaian ini adalah (a) Tes hasil belajar: Untuk memperoleh data tentang hasil belajar siswa di pergunakan tes hasil belajar siswa berbentuk essay yang di buat sendiri oleh peneliti. (b) Lembar observasi Berbentuk format isian untuk merekam kehadiran. (c) Angket: Berisi pertanyaanpertanayaan untuk mengunkap respon siswa terhadap pembelajaran Teams Games Tournament. 
Dalam penelitian tindakan kelas, format observasi digunakan untuk merekam data proses belajar mengajar yang dilaksanakan. (a) Observasi atau pengamatan dimaksudkan untuk mengumpulkan berbagai informasi atas aktivitas murid dan guru saat pelaksanaan tindakan di kelas yang meliputi observasi kelompok dan penilaian diri. (b) Tes hasil belajar digunakan untuk memperoleh data hasil belajar murid setelah mempelajari bahan siklus I dan siklus II melalui soal evaluasi. (c) Angket merupakan salah satu alat pengumpul data dalam asesmen non tes, berupa serangkaian pertanyaan atau pernyataan yang di ajukan kepada responden (peserta didik, orang tua, atau masyarakat).Tekhnik analisis data yang digunakan adalah tekhnik analisis data yang dikembangkan oleh Miles dan Huberman yang terdiri dari tiga tahap kegiatan, yaitu :(1) mereduksi data, (2) menyajikan data, (3) menarik kesimpulan dan verifikasi.

\section{PEMBAHASAN}

Berdasarkan pengamatan peneliti selama ini proses belajar mengajar mata pelajaran PKn murid kelas IV SD Negeri 26 Tamanroja diketahui bahwa masih terdapat beberapa masalah yang kiranya perlu dipecahkan oleh guru sehingga tujuan pembelajaran PKn dapat tercapai secara maksimal. Masalah-masalah tersebut antara lain: 1) dari sisi guru; berupa penguasaan kelas yang kurang, pengelolaan proses belajar mengajar yang terkesan biasa saja, kurang sistematis, intensitas tugas kelas yang kurang, guru kurang menstimulus aktivitas belajar murid, membiarkan murid yang bermain dengan sesama rekannya, tidak memberikan teguran kepada murid yang ribut, sedangkan 2) dari sisi murid antara lain; banyak murid kurang aktif dalam proses belajar mengajar dengan ciri-ciri; kurang bahkan tidak mengajukan pertanyaan dari materi yang diajarkan, tidak memberikan jawaban atas pertanyaan guru, kurangnya perhatian murid terhadap materi yang dijelaskan guru, bermain dengan sesama rekannya, murid berkeliaran di luar kelas, hal lainnya yaitu; murid kurang antusias mengikuti pelajaran yang ditunjukkan dengan ciriciri; murid tidur dengan menundukkan kepala, bercerita dan bermain secara sembunyi-sembunyi kepada sesama rekannya di bangku tengah dan belakang. Dampaknya adalah hasil belajar pada ulangan formatif secara klasikal mendapat nilai rata-rata kelas 60,80 dengan murid yang tuntas hanya mencapai 20 orang dari 44 jumlah murid dengan kriteria ketuntasan minimal ( $K K M$ ) belajar murid 63,5

\section{Deskripsi siklus I}

Penerapan model pembelajaran teams games tournament (TGT) pada mata pelajaran PKn yaitu sebagai berikut:

1. Perencanaan Tindakan

Pada tahap ini peneliti menyusun perangkat pembelajaran berupa silabus dan rencana pelaksanaan pembelajaran (RPP), dan media gambar. Peneliti menyusun format observasi dan evaluasi pembelajaran serta menyusun dan mendesain skenario pelaksanaan tindakan.

\section{Pelaksanaan Tindakan}

Pelaksanaan tindakan pada siklus I dilaksanakan sebanyak 4 kali pertemuan yaitu pada tanggal 29 maret, 30 maret, 2 april dan 06 april 2013 di ruang kelas IV SD negeri 26 Tamanroja Alokasi waktu pada masing-masing pertemuan adalah $2 \times 35$ menit. Pada pertemuan pertama tanggal 22 Februari, peneliti memberikan materi ajar dan menjelaskan gambaran tentang games dan tournamen secara berkelompok, selanjutnya memberikan tugas kepada masing-masing kelompok untuk mempersiapkan belajar dengan materi pelajaran, yaitu system pemerintahan pusat. Pada pertemuan kedua 30 maret, peneliti menyiapkan perangkat pembelajaran, lembar observasi, serta menyampaikan tujuan pembelajaran teams games tournament (TGT) dan motivasi murid, melaksanakan observasi aktivitas belajar murid melalui format observasi yang telah disiapkan. Pada pertemuan ketiga 2 april peneliti menyiapkan perangkat pembelajaran, lembar observasi, serta menyampaikan tujuan pembelajaran teams games tournament(TGT) dan motivasi murid, melaksanakan observasi aktivitas belajar murid melalui format observasi yang telah disiapkan Dan pada pertemuan keempat 06 maret, peneliti memberikan tes siklus I. Pertemuan 
dilaksanakan selama 8 x 35 menit sesuai dengan desain pembelajaran dan rencana pelaksanaan pembelajaran (RPP). Materi yang di ajarkan adalah system pemerintahan pusat.

\section{Hasil Observasi}

Berikut ini adalah hasil observasi yang dilakukan peneliti guna mengamati aktifitas murid selama proses pembelajaran berlangsung.

Tabel 1: Hasil Observasi Siklus I pada murid kelas IV SD Negeri 26 Tamanroja Kecamatan labakkang kabupaten Pangkep

\begin{tabular}{|c|l|c|c|}
\hline No & \multicolumn{1}{|c|}{ Aspek Yang Diamati } & $\begin{array}{c}\text { Siklus } \\
\text { I }\end{array}$ & $\%$ \\
\hline 1 & $\begin{array}{l}\text { Murid yang hadir saat proses } \\
\text { pembelajaran berlangsung }\end{array}$ & 40 & $91 \%$ \\
\hline 2 & $\begin{array}{l}\text { Murid yang memberikan perhatian } \\
\text { saat guru menjelaskan }\end{array}$ & 38 & $86 \%$ \\
\hline 3 & $\begin{array}{l}\text { Murid yang bertanya mengenai } \\
\text { pembelajaran yang diajarkan }\end{array}$ & 10 & $23 \%$ \\
\hline 4 & $\begin{array}{l}\text { Murid yang aktif maju kedepan } \\
\text { kelas untuk menjawab pertanyaan }\end{array}$ & 20 & $45 \%$ \\
\hline 5 & $\begin{array}{l}\text { Murid yang mampu menemukan } \\
\text { solusi ketika diajukan permasalahan } \\
\text { atau pertanyaan }\end{array}$ & 30 & $68 \%$ \\
\hline 6 & $\begin{array}{l}\text { Murid yang mampu menyimpulkan } \\
\text { pelajaran yang telah berlangsung }\end{array}$ & 35 & $80 \%$ \\
\hline
\end{tabular}

Kehadiran murid menunjukkan 91\%. Karena masih ada beberapa siswa yang tidak hadir.

1. Murid yang memberikan perhatian pada saat guru menjelaskan sebanyak $84 \%$

2. Murid yang mengajukan pertanyaan kepada guru $23 \%$. Ini menandakan bahwa kemampuan dan pemahaman setiap murid berbeda pula.

3. Banyak murid yang mengacungkan tangan ketika guru mempersilahkan murid untuk mengerjakan soal di papan tulis $45 \%$.

4. Adapun murid yang mampu menemukan solusi ketika diberikan permasalahan atau pertanyaan $68 \%$ dari jumlah murid dalam kelas IV. ini menunjukkan bahwa sebagian besar dari mereka sudah mampu menganalisa setiap pertanyaan yang diajukan oleh guru.

5. Sebagian besar dari keseluruhan murid dalam kelas IV mampu menyimpulkan pelajaran yang dipelajari pada setiap pertemuan $80 \%$. Ini menunjukkan bahwa selama pelajaran berlangsung mereka memperhatikan dan memahami apa yang telah diberikan oleh gurunya.

\section{Evaluasi Tindakan I}

Berdasarkan hasil penelitian yang telah dilakukan pada siswa kelas IV SD Negeri 26 Tamanroja Kecamatan Labakkang Kabupaten Pangkep , peneliti memperoleh dan mengumpulkan data melalui instrumen tes tentang skor pemahaman tes siklus I murid kelas IV SD Negeri 26 Tamanroja setelah diterapkan model pembelajaran teams games Tournament (TGT) pada siklus I. Adapun hasil belajar pada Siklus I setelah diadakan tes pada murid kelas IV SD negeri 26 Tamanroja adalah sebagai berikut :

Grafik 1: Skor hasil evaluasi murid kelas IV SD Negeri 26 Tamanroja Kecamatan Labakkang Kabupaten Pangkep setelah diterapkan model pembelajaran teams games tournament (TGT) pada siklus I.

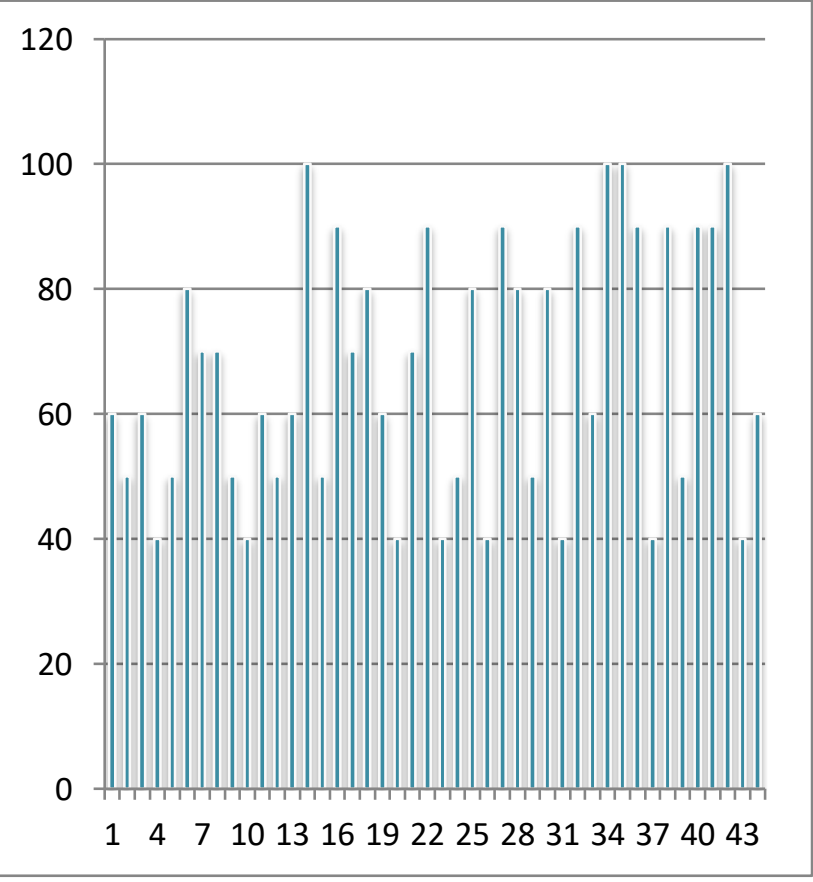

Berdasarkan hasil tes Siklus I pada murid kelas V SD Negeri 26 Tamanroja selanjutnya dianalisis secara deskriptif. Berikut analisis deskriptifnya : 
Rata-rata kelas $=\frac{\text { jumlahnilai keseluruhan }}{\text { jumlahmurid keseluruhan }}=$ $\frac{2910}{44}=66,13$

Adapun distributor skor yang diperoleh dapat disajikan dalam tabel statistik berikut ini :

Tabel 2: Statistik skor hasil belajar PKn murid kelas IV SD Negeri 26 Tamanroja Kecamatan Labakkang Kabupaten Pangkep pada siklus I

\begin{tabular}{lcc} 
NO & STATISTIK & NILAI STATISTIK \\
\hline $\mathbf{1}$ & Subjek Penelitian & 44 \\
$\mathbf{2}$ & Skor Ideal & 100 \\
$\mathbf{3}$ & Skor Maksimum & 90 \\
$\mathbf{4}$ & Skor Minimum & 40 \\
$\mathbf{5}$ & Rentang Skor & 60 \\
$\mathbf{6}$ & Skor rata-rata & 66,13 \\
\hline
\end{tabular}

Dari tabel di atas dilihat bahwa skor rata-rata hasil belajar PKn murid kelas IV SD Negeri 26 tamanroja sebesar 66,13 . Skor yang dicapai murid tersebar dari skor terendah 40 dari yang mungkin dicapai 0 sampai skor tertinggi 90 dari skor ideal yang dicapai 100. Dengan rentang skor 60 ini menunjukkan kemampuan murid cukup bervariasi.

Jika skor hasil belajar siswa dikelommpokkan ke dalam lima kategori,maka diperoleh distribusi frekuensi dan persentase sebagai berikut:

Tabel 3: Distribusi Frekuensi dan persentase skor hasil tes pembelajaran PKn murid kelas IV SD 26 tamanrojar pada tes siklus I

\begin{tabular}{|c|c|c|c|}
\hline Skor & Kategori & Frekuensi & Persentase \\
\hline $0-29$ & Sangat & 0 & $0,00 \%$ \\
\hline $30-49$ & rendah & 8 & $18,18 \%$ \\
\hline $50-69$ & Rendah & 15 & $34,09 \%$ \\
\hline $70-89$ & Sedang & 9 & $20,45 \%$ \\
\hline $90-100$ & $\begin{array}{c}\text { Tinggi } \\
\text { Sangat tinggi }\end{array}$ & 12 & $27,27 \%$ \\
\hline & lah & 44 & $100 \%$ \\
\hline
\end{tabular}

Tabel 3 menunjukkan bahwa presentase hasil belajar PKn siklus I dari 44 murid kelas IV SD Negeri 26 tamanroja kecamatan Labakkkan kabupaten Pangkep, setelah dilaksanakan pembelajaran dengan menggunakan model pembelajaran teams games tournament (TGT), pada siklus I adalah $0 \%$ pada kategori sangat rendah, 8 murid $(18,18 \%)$ pada kategori rendah, 15 murid $(34,09 \%)$ yang berada pada kategori sedang, 9 murid (20,45\%) yang berada pada kategori tinggi, dan 12 murid $(27,27 \%)$ yang berada pada kategori sangat tinggi. Berdasarkan hasil analisis pada tabel 3 di peroleh skor rata-rata hasil belajar murid pada siklus I sebesar 66,13. Seluruh murid hadir pada saat pemberian tes akhir siklus I.

Tabel 4. Deskripsi Ketuntasan Belajar Murid pada Siklus I

\begin{tabular}{cccc}
\hline Skor & Kategori & Frekuensi & Persentase \\
\hline $\mathbf{0 - 6 9}$ & Tidak & 23 & $52,27 \%$ \\
$\mathbf{7 0 -}$ & Tuntas & 21 & $47,72 \%$ \\
$\mathbf{1 0 0}$ & Tuntas & & \\
\hline \multicolumn{2}{c}{ Jumlah } & $\mathbf{4 4}$ & $\mathbf{1 0 0}$
\end{tabular}

Diagram 2 : Hasil analisis belajar siklus I

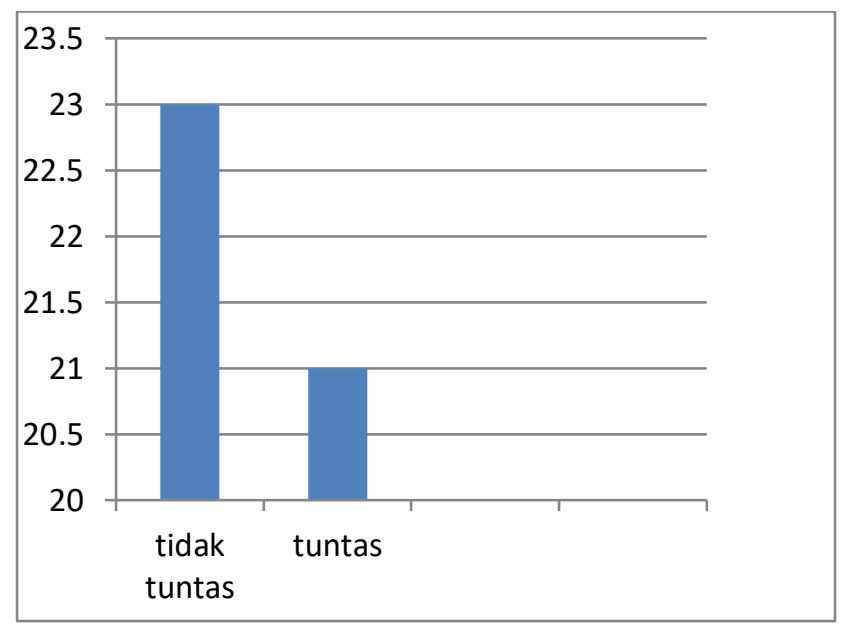

Dari Tabel 4 dan Diagram 2 menunjukkan bahwa pada siklus I persentase ketuntasan murid sebesar 52,27 \% yaitu 23 murid dari 44 murid termasuk kategori tuntas dan $47,72 \%$ yaitu 21 murid dari 44 murid termasuk kategori tidak tuntas. 5. Refleksi Siklus I

Berdasarkan hasil observasi dan tes siklus I, peneliti dapat merefleksikan beberapa hal yaitu : Pada Siklus I peneliti menggunakan metode langsung(ceramah) dan kelompok. Secara keseluruhan dari pertemuan pertama hingga pertemuan keempat kehadiran cukup baik. Begitu pula dengan perhatian dan keaktifan mereka dalam proses pembelajaran, semakin lama semakin meningkat.

Tetapi kurangnya buku paket dan kelebihan peserta didik yang mencapai hingga 44 murid, 
menjadi kendala pada sebagian siswa karena mereka terlihat kesulitan memahami soal yang diberikan, dan membutuhkan waktu yang cukup banyak untuk memerankan peran yang di tugaskan serta mencatat semua materi yang diberikan. Sehingga peneliti menyimpulkan bahwa dalam pelajaran PKn sebaiknya siswa memiliki buku paket sendiri. Oleh sebab itu pada siklus berikutnya peneliti akan memberikan lebih banyak soal-soal yang akan dikerjakan oleh kelompok yang telah ditentukan.

\section{Deskripsi siklus II}

Penerapan pembelajaran PKn pada siklus II melalui model pembelajaran teams games tournament (TGT) yaitu sebagai berikut:

\section{Perencanaan Tindakan}

Pada tahap ini peneliti bersama guru kelas mendiskusikan perencanaan tindakan yang akan dilakukan pada proses pembeljaran dalam siklus II ini. Peneliti juga menjelaskan tentang strategi yang akan di gunakan dalam proses belajar mengajar . Dalam tahap ini pula dibuat beberapa perangkat pembelajaran guna menunjang proses tersebut. Antara lain rencana pelaksanaan pembelajaran (RPP), lembar observasi,dan instrument hasil belajar (tes).

\section{Pelaksanaan Tindakan}

Pelaksanaan tindakan pada siklus II dilaksanakan sebanyak 4 kali pertemuan yaitu pada tanggal 9 april, 13 april, 16 april dan 20 april 2013 di ruang kelas IV SD negeri 26 Tamanroja Kecamatan Labakkang kabupaten Pangkep. Pada pertemuan kelima tanggal 9 april 2013, peneliti melanjutkan pelajaran setelah selesainya diadakan tes siklus I pada pertemuan sebelumnya. Selanjutnya peneliti memberikan lebih banyak tugas dan permasalahan kepada masing-masing kelompok agar murid menyelesaikan dengan cara teams games tournament (TGT). Pada pertemuan keenam 13 april, peneliti memberikan Igames dan tournament pada murid. Pada pertemuan ketujuh 16 april, peneliti memberikan games dan tournament pada murid, Dan pada pertemuan kedelapan 20 april, peneliti memberikan tes siklus II. Pertemuan dilaksanakan selama 8 × 35 menit sesuai dengan desain pembelajaran dan rencana pelaksanaan pembelajaran (RPP). Materi yang di ajarkan adalah globalisasi. Pada kegiatan awal guru, pertama-tama guru mengucapkan salam dan membuka pelajaran. Setelah itu, guru melakukan apersepsi untuk menggali kembali pengetahuan murid tentang materi yang telah dipelajari. Kegiatan ini berlangsung selama 5 menit. Pada kegiatan inti dilakukan selama 55 menit. Kegiatan guru diawali dengan menampilkan alat bantu mengajar. Model pembelajaran yang digunakan adalah model pembelajaran teams games tournament (TGT) dan alat bantunya adalah gambar yang mewakili tiap kelompok. Kegiatan selanjutnya, yaitu membagi murid secara heterogen dalam kelompok kecil 5 - 6 orang, guru menyampaikan materi yang akan dipelajari, guru kembali mengarahkan cara bermain peran sama seperti siklus I, memberikan lembar kerja siswa kepada tiap-tiap kelompok, mengawasi dan membimbing kelompok belajar siswa, melaporkan hasil diskusi dan memberikan penguatan. Pada kegiatan akhir selama 10 menit, yaitu menutup pembelajaran yang dilanjutkan dengan pesan-pesan moral.

Pada pelaksanaan siklus II terdapat kemajuan dalam diri murid hal ini ditandai dengan adanya perubahan meliputi:

a. Suasana pembelajaran lebih terarah dan keaktifan murid dalam pembelajaran meningkat baik secara individu maupun kelompok.

b. Murid tampak bergairah dan aktif dalam kegiatan pembelajaran,

c. Murid aktif mengajukan pertanyaan dan lebih siap untuk melaporkan hasil kerja kelompoknya,

d. Murid berani mengemukakan pendapat,

e. murid dapat membuat kesimpulan akhir dan mempresentasikan di depan kelas.

f. Murid mampu menyelesaikan tugas tepat waktu.

3. Hasil Observasi

Berikut ini adalah hasil observasi yang dilakukan peneliti guna mengamati aktifitas murid selama proses pembelajaran berlangsung. 
Tabel 5: Hasil Observasi Siklus II pada murid kelas IV SD Negeri 26 Tamanroja Kecamatan labakkang Kabupaten Pangkep

\begin{tabular}{|c|l|c|c|}
\hline No & \multicolumn{1}{|c|}{ Aspek Yang Diamati } & $\begin{array}{c}\text { Siklus } \\
\text { I }\end{array}$ & $\%$ \\
\hline 1 & $\begin{array}{l}\text { Murid yang hadir saat proses } \\
\text { pembelajaran berlangsung }\end{array}$ & 43 & $97 \%$ \\
\hline 2 & $\begin{array}{l}\text { Murid yang memberikan } \\
\text { perhatian saat guru menjelaskan }\end{array}$ & 38 & $86 \%$ \\
\hline 3 & $\begin{array}{l}\text { Murid yang bertanya mengenai } \\
\text { pembelajaran yang diajarkan }\end{array}$ & 18 & $40 \%$ \\
\hline 4 & $\begin{array}{l}\text { Murid yang aktif maju kedepan } \\
\text { kelas untuk menjawab pertanyaan }\end{array}$ & 30 & $68 \%$ \\
\hline 5 & $\begin{array}{l}\text { Murid yang mampu menemukan } \\
\text { solusi ketika diajukan } \\
\text { permasalahan atau pertanyaan }\end{array}$ & 34 & $77 \%$ \\
\hline 6 & $\begin{array}{l}\text { Murid yang mampu } \\
\text { menyimpulkan pelajaran yang } \\
\text { telah berlangsung }\end{array}$ & $84 \%$ \\
\hline
\end{tabular}

Berdasarkan tabel 5 dapat dinyatakan atau disimpulkan bahwa :

a. Kehadiran murid mulai dari pertemuan keempat hingga pertemuan keenam menunjukkan $97 \%$. Terlihat adanya peningkatan kehadiran dari siklus sebelumnya.

b. Murid yang memberikan perhatian pada saat guru menjelaskan $86 \%$. Murid ini begitu antusias memperhatikan pelajaran yang diberikan.

c. Murid yang mengajukan pertanyaan kepada guru $40 \%$.

d. Banyak murid yang mengacungkan tangan ketika guru mempersilahkan murid untuk mengerjakan soal di papan tulis $68 \%$.

e. Adapun murid yang mampu menemukan solusi ketika diberikan permasalahan atau pertanyaan 77\% lebih dari 50\% dari jumlah murid dalam kelas IV. ini menunjukkan bahwa sebagian besar dari mereka sudah mampu menganalisa setiap pertanyaan yang diajukan oleh guru.

f. Sebagian besar dari keseluruhan murid dalam kelas IV mampu menyimpulkan pelajaran yang dipelajari pada setiap pertemuan yakni $84 \%$. Ini menunjukkan bahwa selama pelajaran berlangsung mereka memperhatikan dan memahami apa yang telah diberikan oleh gurunya.

4. Evaluasi Tindakan II

Berdasarkan hasil penelitian yang telah dilakukan pada siswa kelas IV SD Negeri 26 Tamanroja Kecamatan Labakkang kabupaten Pangkep, peneliti memperoleh dan mengumpulkan data melalui instrumen tes tentang skor pemahaman tes siklus II murid kelas IV SD Negeri 26 tamanroja Kecamatan labakkang Kabupaten Pangkep setelah diterapkan model pembelajaran teams games Tournament (TGT) pada siklus II. Adapun hasil belajar pada Siklus II setelah diadakan tes pada murid kelas IV SD Negeri 26 Tamanroja Kecamatan Labakkang kabupaten pangkep adalah sebagai berikut :

Diagram 3 Skor hasil belajar murid kelas IV SD Negeri 26 Tamanroja Kecamatan labakkang kabupaten Pangkep setelah diterapkan model pembelajaran team pada ss Games Tournament (TGT) siklus II

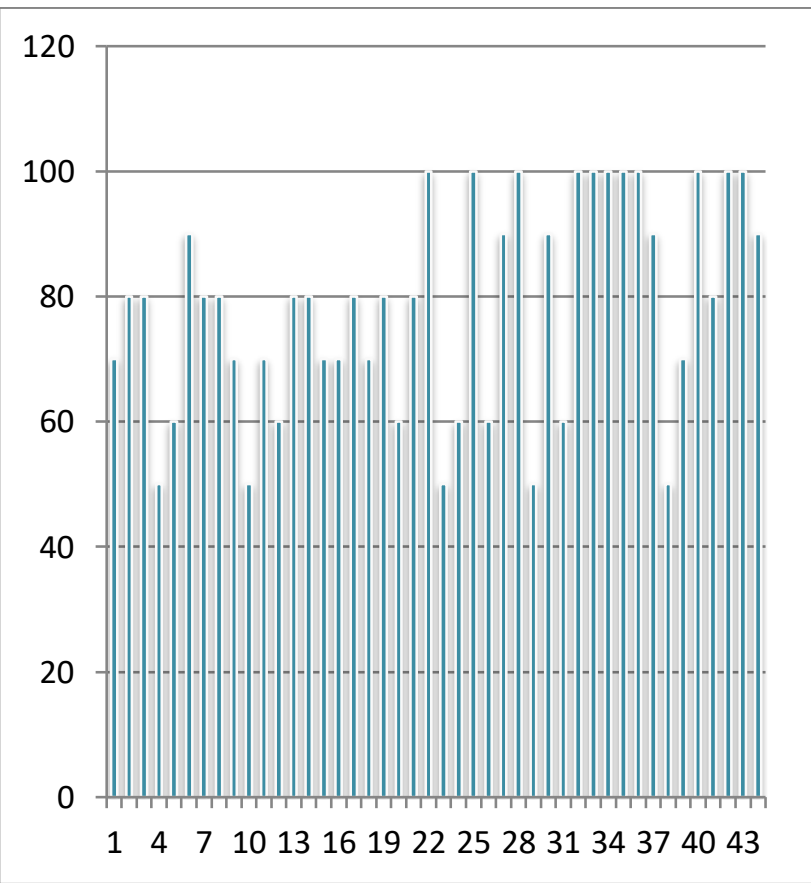

Berdasarkan hasil tes Siklus II pada murid kelas IV SD Negeri 26 tamanroja kecamatan labakkang kabupaten Pangkep selanjutnya dianalisis secara deskriptif. Berikut analisis deskriptifnya :

Rata-rata kelas $=\frac{\text { jumlahnilai } \text { keseluruhan }}{\text { jumlahmurid keseluruhan }}=$ $\frac{3480}{44}=79.09$ 
Adapun distributor skor yang diperoleh dapat disajikan dalam tabel statistik berikut ini : Tabel 6 : Statistik skor hasil belajar PKn murid kelas IV SD Negeri 26 Tamanroja Kecamatan Labakkang Kabupaten Pangkep pada siklus II

\begin{tabular}{lcc}
\hline NO & STATISTIK & NILAI STATISTIK \\
\hline $\mathbf{1}$ & Subjek Penelitian & 44 \\
$\mathbf{2}$ & Skor Ideal & 100 \\
$\mathbf{3}$ & Skor Maksimum & 95 \\
$\mathbf{4}$ & Skor Minimum & 50 \\
$\mathbf{5}$ & Rentang Skor & 35 \\
$\mathbf{6}$ & Skor rata-rata & 79,09 \\
\hline
\end{tabular}

Dari tabel 6 dilihat bahwa skor rata-rata hasil belajar PKn murid kelas V SD Negeri 26 Tamanroja kecamatan Labakkang kabupaten Pangkep pada siklus II sebesar 79,09.Skor yang dicapai murid tersebar dari skor terendah 60 dari yang mungkin dicapai 0 sampai skor tertinggi 95 dari skor ideal yang dicapai 100 . Dengan rentang skor 35 ini menunjukkan kemampuan murid cukup bervariasi. Jika skor hasil belajar siswa dikelommpokkan ke dalam lima kategori,maka diperoleh distribusi frekuensi dan persentase sebagai berikut:

Tabel 7: Distribusi Frekuensi dan persentase skor hasil tes pembelajaran PKn murid kelas IV SD Negeri 26 Tamanroja Kecamatan Labakkang Kabupaten Pangkep pada tes siklus II

\begin{tabular}{cccc}
\hline Skor & Kategori & Frekuensi & Persentase \\
\hline $0-29$ & Sangat & 0 & $0 \%$ \\
$30-49$ & rendah & 0 & $0 \%$ \\
$50-69$ & Rendah & 10 & $22,27 \%$ \\
$70-89$ & Sedang & 17 & $38,63 \%$ \\
$90-100$ & Tinggi & 17 & $38,63 \%$ \\
& Sangat tinggi & & \\
\hline & Jumlah & $\mathbf{4 4}$ & $\mathbf{1 0 0 \%}$ \\
\hline
\end{tabular}

Tabel 7 menunjukkan bahwa presentase hasil belajar PKn siklus II dari 44 murid kelas IV SD, setelah dilaksanakan pembeNegeri 26 Tamanroja Kecamatan Labakkang Kabupaten Pangkep dengan menggunakan model pembelajaran teams games tournament (TGT), pada siklus II adalah 0\% pada kategori sangant rendah,0\% pada kategori rendah, 10 murid $(22,27 \%)$ yang berada pada kategori sedang, 17 murid $(38,63 \%)$ yang berada pada kategori tinggi, dan 17 murid (38,63\%) yang berada pada kategori sangat tinggi. Berdasarkan hasil analisis pada tabel 6 di peroleh skor rata-rata hasil belajar murid pada siklus II sebesar 79,09. Seluruh murid hadir pada saat pemberian tes akhir siklus II.

Apabila skor hasil tes dikategorikan berdasarkan ketuntasan belajar siswa pada tes akhir siklus II,maka kategori tuntas dan belum tuntas dapat dilihat pada tabel 11.

Tabel 8. Deskripsi Ketuntasan Belajar Murid pada Siklus II

\begin{tabular}{cccc}
\hline Skor & Kategori & Frekuensi & $\%$ \\
\hline $0-69$ & Tidak Tuntas & 10 & $22,27 \%$ \\
$70-100$ & Tuntas & 34 & $77,27 \%$ \\
\hline \multicolumn{2}{c}{ Jumlah } & $\mathbf{4 4}$ & $\mathbf{1 0 0 \%}$ \\
\hline
\end{tabular}

Diagram 4: Hasil analisis belajar siklus II

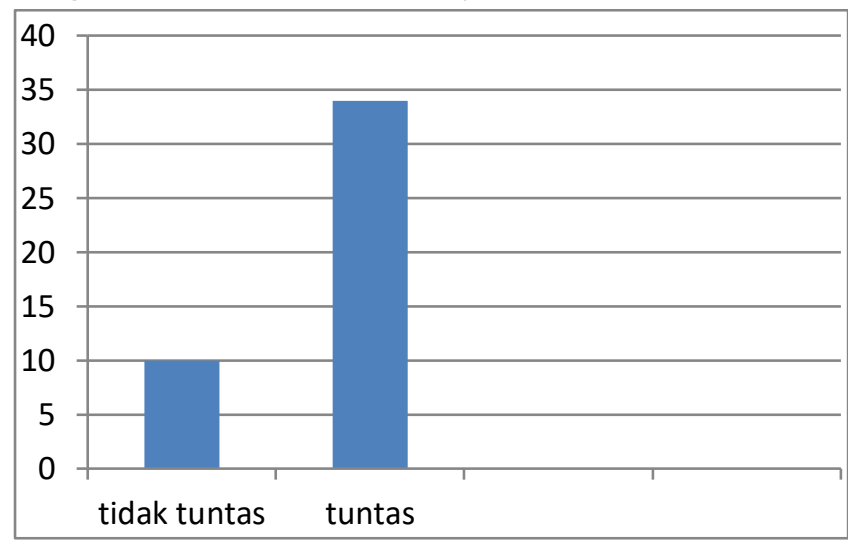

Dari Tabel 8 dan diagram 4 menunjukkan

bahwa $22,27 \%$ murid termasuk dalam kategori belum tuntas dan $77,27 \%$ dalam kategori tuntas,jadi, data diatas pada siklus II sudah menunjukkan bahwa hasil belajar siswa tuntas, walaupun masih ada beberapa murid yang belum tuntas, sebab secara klasikal apabila minimal $75 \%$ dari jumlah murid yang telah tuntas belajar,maka ini dapat dikategorikan tuntas.

Tabel 12 Deskripsi perbandingan ketuntasan belajar murid pada siklus I dan siklus II

\begin{tabular}{cccccc}
\hline \multirow{2}{*}{ Skor } & \multicolumn{2}{c}{ Siklus I } & \multicolumn{2}{c}{ Siklus II } & Kat \\
\cline { 2 - 6 } & Frek & \% & Frek & $\%$ & \\
\hline 0-69 & 23 & $52,27 \%$ & 10 & 22, & Tidak \\
& & & & $27 \%$ & tuntas \\
\hline $70-100$ & 21 & $47,72 \%$ & 34 & 77, & Tunta \\
& & & & $27 \%$ & s
\end{tabular}


Diagram 6: Perbandingan Ketuntasan Hasil Belajar Murid dari Siklus I Ke Siklus II

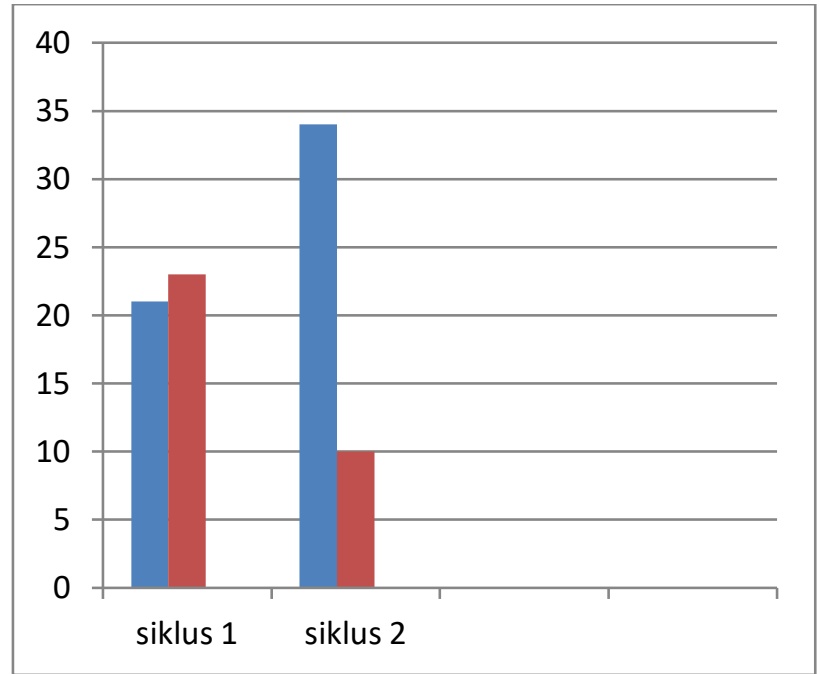

Keterangan

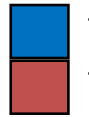

Tuntas

Tidak tuntas

Berdasarkan tabel 12 dideskripsikan bahwa ketuntasan belajar murid dengan kategori "Tidak tuntas" pada siklus I sebesar 52,27\% menurun menjadi 47,72\% pada siklus II, dan kategori "Tuntas" pada siklus I sebesar 22,27\% menjadi $77,27 \%$ pada siklus II.

\section{Refleksi siklus II}

Berdasarkan hasil observasi dan tes siklus II, penulis dapat merefleksikan beberapa hal yaitu : Pada siklus II penulis menggunakan metode langsung (ceramah) dan kelompok. Secara keseluruhan dari pertemuan keempat hingga pertemuan keenam kehadiran menunjukkan 100\%. Begitu pula dengan perhatian dan keaktifan mereka dalam proses pembelajaran, semakin lama semakin meningkat. Kemampuan untukmemahami materi juga begitu meningkat, terbukti dengan lebih banyaknya soal yang mampu diselesaikan dengan baik. Jika dibandingkan dengan siklus I, pada siklus II pemahaman siswa terhadap materi yang diajarkan meningkat secara signifikan. Ini ditandai dengan hasil belajar yang lebih baik dibandingkan sebelumnya. Dengan demikian, strategi yang diterapkan oleh peneliti mampu meningkatkan hasil belajar pada siswa kelas IV SD Negeri 26 Tamanroja Kecamatan labakkang Kabupaten Pangkep.

\section{Pembahasan Tiap Siklus I}

Berdasarkan hasil pengamatan pada siklus I maka pembahasan didasarkan pada materi yang berkaitan dengan metode/teknik yang digunakan untuk meningkatkan pemahaman materi pada murid kelas IV SD Negeri 26 Tamanroja Kecamatan Labakkang Kabupaten Pangkep di mana dengan menggunakan model pembelajaran teams games tournament (TGT) dalam pembelajaran PKn dapat meningkatkan hasil belajar PKn para murid karena melalui model ini murid bebas menuangkan semua ide-idenya ataupun pendapatnya dengan bebas tanpa ada rasa takut. Dari hasil observasi aktivitas murid dalam pembelajaran siklus I ditemukan masih ada murid yang pasif menjawab pertanyaan yang dilontarkan oleh guru, mengajukan pertanyaan, mengajukan tanggapan, mencatat/mengerjakan tugas, kurang kerjasama dalam kelompok, kurang menghormati pendapat teman, malu meminta bimbingan, dan masih ada murid yang mengganggun teman dalam pembelajaran. Dari hasil tes yang diberikan pada siklus I diperoleh data bahwa pemahaman murid masih dalam ketegori sedang, dari 44 murid yang mengerjakan tes pada siklus I nilai rata-rata yang diperoleh murid adalah $66,13 \%$.

\section{Pembahasan Tiap Siklus II}

Berdasarkan hasil pengamatan pada siklus II maka pembahasan didasarkan pada materi yang berkaitan dengan metode/teknik yang digunakan untuk meningkatkan pemahaman materi pada murid kelas IV SD Negeri 26 Tamanroja Kecamatan Labakkang Kabupaten Pangkep di mana dengan menggunakan model pembelajaran teams games tournament (TGT) dalam pembelajaran PKn dapat meningkatkan hasil belajar PKn para murid karena melalui model ini murid bebas menuangkan semua ide-idenya ataupun pendapatnya. Pada siklus II, 8 item aktivitas murid yang diamati pada siklus pertama mengalami peningkatan. Dari hasil tes yang diberikan pada siklus II diperoleh data bahwa pemahaman murid masih dalam ketegori tinggi, dari 44 murid yang mengerjakan tes pada siklus II nilai rata-rata yang diperoleh murid adalah $77,27 \%$. 
Berdasarkan data nilai hasil dari, tes akhir siklus 1 dan siklus II, yaitu pada siklus I nilai ratarata yang diperoleh murid adalah $66,13 \%$, dan pada siklus II nilai rata-rata yang diperoleh murid adalah $77,27 \%$. keseluruhan tindakan dalam penelitian ini terlihat adanya peningkatan hasil belajar pada murid kelas IV SD Negeri 26 Tamanroja kecamatan Labakkang kabupaten Pangkep. Berdasarkan data tersebut maka disimpulkan bahwa pembelajaran ini sudah berhasil sesuai target yang telah ditetapkan

\section{KESIMPULAN}

Berdasarkan hasil analisis data dan
pembahasan yang telah diuraikan pada bab sebelumnya, maka dapat disimpulkan bahwa pembelajaran Teams Games Tournament (TGT) memberikan dampak positif terhadap peningkatan hasil belajar PKn dan terjadi perubahan aspek kognitif yang meningkat pada murid kelas IV SD Negeri 26 Tamanroja Kecamatan Labakkang Kabupaten Pangkep selama pelaksanaan tindakan. Hal ini dapat terlihat pada hasil belajar PKn murid kelas IV SD Negeri 26 Tamanroja Kecamatan Labakkang Kabupaten Pangkep melalui pembelajaran Teams Games Tournament (TGT) mengalami peningkatan. Hal ini terlihat dari nilai rata-rata setelah dilaksanakannya siklus I hasil belajar murid masih berada pada kategori rendah dengan rata - rata $66,13 \%$, kemudian nilai ratarata pada siklus II sebesar $79,09 \%$ artinya terjadi peningkatan sebesar $12,96 \%$ mencapai ketuntasan hasil belajar PKn murid kelas IV SD Negeri 26 Tamanroja Kecamatan Labakkang Kabupaten Pangkep.

\section{DAFTAR PUSTAKA}

[1] Anitah, (2009). Proses Pembelajaran. Bandung: Rosada Karya

[2] Anni. (2006). Belajar dan Pembelajaran. Jakarta: PT Citra

[3] Baharuddin. (2010). Kurikulum dan Pembelajaran. Bandung Sinar Baru

[4] Depdiknas. 2005. Peraturan Pemerintah Nomor 19 Tahun (2005) tentang Standar Nasional Pendidikan pasal 6 ayat (1)

[5] Djamarah, (2008). Pengembangan Aktivitas Belajar. Jakarta: Grafindo

[6] Gagne dan Berliner. (1983). Kondisi Belajar dan Teori Pembelajaran. Jakarta: Depdikbud Dirjend. Dikti
[7] Hasibuan. (2009). Teknologi Pengajaran. Bandung: Sinar Baru

[8] Johnson D.W. dan Johnson R.T. (1994). Model-model Pembelajaran. Bandung: PT kencana

[9] Kunandar. (2011). Langkah Mudah Penelitian Tindakan Kelas Sebagai Pengembangan Profesi Guru. Jakarta: RajaGrafindo Persada

[10] Miles. (1980). Qualitive data Analisis A Sourcebook of New Methods. London Sage Publication

[11] Muljono. (2006). Kurikulum dan embelajaran. Bandung: Remaja Rosdakarya

[12] Rusman. (2011). Modul Pendekatan dan Model Pembelajaran. Bandung: Universitas Pendidikan Indonesia

[13] Saco. (2006). Model Pembelajaran Kooperatif. Jakarta: Nusa Indah

[14] Sagala. (2005). Belajar dan Pembelajaran. Jakarta: PT Gramedia

[15] Sardiman. (2011). Meningkatkan Proses Hasil pembelajaran. Bandung: CV Diponegoro

[16] Slavin E. (2005). Cooperative Learning. Bandung: Nusa Media

[17] Somantri. (2001). Pendekatan Pembelajaran. Jakarta: Kencana Group

[18] Sudjana, Nana. (1989). Dasar-dasar Proses Belajar Mengajar. Bandung : Sinar Baru Algensido Offset.

[19] Sugandi. (2005). Kemamuan Dasar Guru dalam proses Belajar Mengajar. Bandung: PT Remaja Rosdakarya

[20] Sukirman. (2007). Keteramilan Dasar Mengajar. Bandung: New ress

[21] Suprijono, A. (2010). strategi Pembelajaran. Bandung: Agung Persada

[22] Suardi, S. (2018). Peningkatan Hasil Belajar Sosiologi Pokok Bahasan Interaksi Sosial Melalui Metode Diskusi pada Siswa Kelas X MA. Muhammadiyah Panaikang Kacamatan Bissappu Kabupten Bantaeng. " JURNAL ETIKA DEMOKRASI (JED)" PRODI PPKn FKIP UNISMUH MAKASSAR, 2(1).

[23] Winataputra, (2008): Teori Pembelajaran. Jakarta: Bumi Aksara 